\title{
GCU
}

Glasgow Caledonian

University

University for the Common Good

\section{A systematic review to evaluate the evidence base for the World Health Organization's adopted hand hygiene technique for reducing the microbial load on the hands of healthcare workers}

Price, Lesley; Melone, Lynn; McLarnon, Nichola; Bunyan, Donald ; Kilpatrick, Claire; Flowers, Paul; Reilly, Jacqueline

Published in:

American Journal of Infection Control

DOI:

10.1016/j.ajic.2018.01.020

Publication date:

2018

Document Version

Author accepted manuscript

Link to publication in ResearchOnline

Citation for published version (Harvard):

Price, L, Melone, L, McLarnon, N, Bunyan, D, Kilpatrick, C, Flowers, P \& Reilly, J 2018, 'A systematic review to evaluate the evidence base for the World Health Organization's adopted hand hygiene technique for reducing the microbial load on the hands of healthcare workers', American Journal of Infection Control, vol. 46, no. 7, pp. 814-823. https://doi.org/10.1016/j.ajic.2018.01.020

\section{General rights}

Copyright and moral rights for the publications made accessible in the public portal are retained by the authors and/or other copyright owners and it is a condition of accessing publications that users recognise and abide by the legal requirements associated with these rights.

Take down policy

If you believe that this document breaches copyright please view our takedown policy at https://edshare.gcu.ac.uk/id/eprint/5179 for details of how to contact us. 
Title: A Systematic Review to evaluate the evidence base for the World Health Organization's adopted Hand Hygiene Technique for reducing the microbial load on the hands of Healthcare Workers

\section{Authors:}

Lesley Price $^{\mathrm{a}} \mathrm{PhD}^{*}$, Lynn Melone ${ }^{\mathrm{a}} \mathrm{BSc}(\mathrm{Hons})$, Nichola McLarnon ${ }^{\mathrm{a}} \mathrm{PhD}$, Donald Bunyan ${ }^{\mathrm{b}}$ BSc(Hons), Claire Kilpatrick ${ }^{\mathrm{c}} \mathrm{MSc}$, Paul Flowers ${ }^{\mathrm{a}} \mathrm{PhD}$, Jacqueline Reilly ${ }^{\mathrm{a}} \mathrm{PhD}$

${ }^{a}$ Department of Nursing and Community Health, School of Health and Life Sciences, Glasgow Caledonian University, Glasgow, Scotland, UK

${ }^{\mathrm{b}}$ Healthcare Associated Infections \& Infection Control Section, Health Protection Scotland, NHS National Services Scotland, Meridian Court, 5 Cadogan Street, Glasgow, G2 6QE, UK

${ }^{\mathrm{c}}$ Consultant to the World Health Organisation, Service Delivery and Safety Department, 20 Avenue Appia, Geneva, Switzerland

*Address correspondence to Dr Lesley Price, Department of Nursing and Community Health, School of Health and Life Sciences, Glasgow Caledonian University, Cowcaddens Road, Glasgow G4 0BA, Scotland, UK

Telephone number: +441413313431

E-mail address: L.Price@gcu.ac.uk 
Background: Effective hand hygiene prevents healthcare-associated infections. This systematic review evaluates the evidence for the World Health Organization's (WHO) technique, in reducing the microbial load on healthcare workers' (HCW) hands.

Methods: Conducted in accordance with Joanna Briggs Protocol 531. Index and free text terms for technique, HCW and microbial load were searched in CINAHL, Medline, Web of Science, Mednar, Proquest and Google scholar. Inclusion criteria were papers in English evaluating the WHO six-step hand hygiene technique in healthcare staff. Quality assessment and data extraction were independently performed by two reviewers.

Results: All seven studies found the WHO technique reduced bacterial load on HCW hands but the strongest evidence came from three randomized controlled trials, which provided conflicting evidence. One found no difference in the effectiveness of the WHO six-step compared to the Centers for Disease Control and Prevention's three-step technique ( $\mathrm{p}=0.08)$, while another found the WHO six-step more effective $(\mathrm{p}=0.02)$ and the third that a modified three-step technique more effective than the six-step technique $(\mathrm{p}=0.021)$.

Conclusions: This review provides evidence of effectiveness of the WHO technique but does not identify the most effective hand hygiene technique. Questions to be addressed by further research are identified. Current practice should continue meanwhile.

Keywords: hand hygiene; technique; systematic review; microbial load

Disclosure statement: No conflicts of interest 


\section{Background}

Hand hygiene represents a cornerstone of infection prevention. Whilst superficially at least it may be understood as a relatively simple procedure, its use in a range of real world settings highlights a surprising degree of complexity. The importance of hand hygiene in saving patient lives was first demonstrated in $1847 .{ }^{1}$ Since that time research has continued to focus upon understanding hand hygiene; establishing links between the contamination of the hands of healthcare staff and problems concerning both epidemics and endemic healthcareassociated infections. ${ }^{2,3}$ It is widely acknowledged that effective hand hygiene amongst healthcare staff is one of the most important infection prevention strategies available, ${ }^{4,5}$ yet uncertainty remains concerning a range of issues relating to hand hygiene. ${ }^{1}$

One major issue relates to which technique to use when performing hand hygiene. ${ }^{5-10}$ The WHO recommends ${ }^{1}$ the adoption of a hand hygiene technique originally developed by Professor Graham Ayliffe in 1978. ${ }^{11}$ This approach, called the WHO six-step technique in this review, focuses on the physical rubbing of specific areas of the hands and involves the following procedures: palm to palm friction; right palm over left dorsum with interlaced fingers and vice versa; palm to palm with fingers interlaced; back of fingers to opposing palms with fingers interlaced; rotational rubbing of left thumb clasped in right palm and vice versa; rotational rubbing backwards and forwards with clasped fingers of right hand in left palm and vice versa. ${ }^{1}$

This technique was originally developed to standardize testing of hand hygiene products not for performing hand hygiene in clinical practice. ${ }^{11}$ It has now been adopted globally as the gold standard for hand hygiene ${ }^{12}$ for use in clinical practice, albeit compliance is low. ${ }^{13-15}$ One possible way to increase compliance with the technique is to provide $\mathrm{HCW}$ with evidence of why it is important, ${ }^{16}$ in this case, to decontaminate their hands using the recommended technique. In addition given the technique was devised for testing hand 
hygiene products and not for use in clinical practice, a review providing this evidence would still be helpful. Thus, the objective of this systematic review was to evaluate the evidence for the WHO hand hygiene technique in reducing microbial load on the hands of HCW.

\section{Methods}

Details of the study protocol, its inclusion criteria and the particularities of data analysis are documented in the protocol, which is registered with the Joanna Briggs Institute. ${ }^{17}$

\section{Inclusion criteria}

Studies were included if they named the WHO six-step technique or a variation of the technique; described the technique they used which was consistent with the WHO six-step technique or cited the WHO six-step technique in the methods. Inclusion criteria also included HCW performing either handrub or handwashing within any healthcare context, within any country.

\section{Exclusion criteria}

Studies based within operating theatres using surgical hand asepsis were excluded, as the hand hygiene technique and duration differs within this setting. Studies were also excluded if they were not specifically about hand hygiene technique but were investigating the efficacy of hand hygiene products or evaluating hand hygiene compliance. Studies not conducted with HCW were excluded as were those which were not primary research or which did not measure microbial load.

\section{Outcomes}

The primary outcome required in the reviewed studies was reduction in the microbial load of HCW hands following application of the aforementioned hand hygiene technique. Secondary outcomes were a measure of hand coverage and time of hand decontamination alongside, but not instead of, microbial load. 


\section{Types of study}

The review considered randomized controlled trials (RCTs), non-randomized controlled trials, before and after studies, case control studies, cohort studies and observational descriptive studies to enable the identification of the current available evidence.

\section{Search strategy}

A three-step search strategy was employed. Keywords and index terms were searched in CINAHL, Medline, Proquest and Web of Knowledge databases. Advice was sought from a Librarian to ensure the development of a comprehensive search strategy using a combination of keywords and index terms. The full search for Medline (Appendix) was individualised for the other databases according to their functionality. The search strategy included papers published in the English language between 1978 (as this was the first date the authors were aware of the technique being used) and May 2017. Secondly, as keyword terms could not be combined in Mednar and Google Scholar, only the broadest keywords were searched in these databases. Finally, the reference lists of potential papers identified for possible inclusion in the review were searched.

\section{Study selection}

The titles and abstracts of the identified papers retrieved from the searches were stored and screened for relevance independently by two reviewers according to the inclusion criteria relating to study design, population, intervention and outcomes, as described above. Full text of papers, meeting the inclusion criteria from the title and abstract search, and those where there was insufficient evidence in the title and abstract to make a decision, were reviewed independently by two reviewers. Discrepancies were discussed and agreed between two reviewers. 


\section{Quality assessment and data extraction}

Full text copies of included papers were independently reviewed by two reviewers to assess their quality. The reviewers used standardized critical appraisal checklists for descriptive/case series and experimental studies ${ }^{18}$ as appropriate for the study designs.

Data were independently extracted by the two reviewers using an original comprehensive data extraction tool adapted by the authors from standardized data extraction tools. ${ }^{17,18}$ The standardized tool was expanded to include details pertinent to the review such as identifying the detail of the participants, intervention delivery and outcomes required.

The results are presented in a narrative summary as meta-analysis was not appropriate due to substantial heterogeneity of the design and outcomes.

\section{Results}

\section{Search results}

Figure 1 depicts the database search results. At stage one 23081 bibliographic records were identified through database searching, 2125 of these were duplicates, resulting in 20956 records being eligible for stage two of the process. Most of the records $(n=20948)$ did not meet the inclusion criteria as they were not empirical studies, participants were not HCW, the aim of the studies was to test a product or to measure hand hygiene compliance, the hand hygiene technique used in the study was not the WHO six-step technique or the techniques used could not be identified..

As a result, seven papers were eligible for inclusion: Widmer et al (2007), ${ }^{19}$ Laustsen et al (2008), ${ }^{7}$ Tschudin-Sutter et al (2010), ${ }^{20}$ Chow et al (2012), ${ }^{21}$ Pires et al (2017), ${ }^{22}$ Reilly et al (2016), ${ }^{23}$ Tschudin-Sutter et al (2017). ${ }^{24}$

The characteristics of these studies are reported in table 1. 
Figure I: PRISMA 2009 Flow Diagram ${ }^{25}$
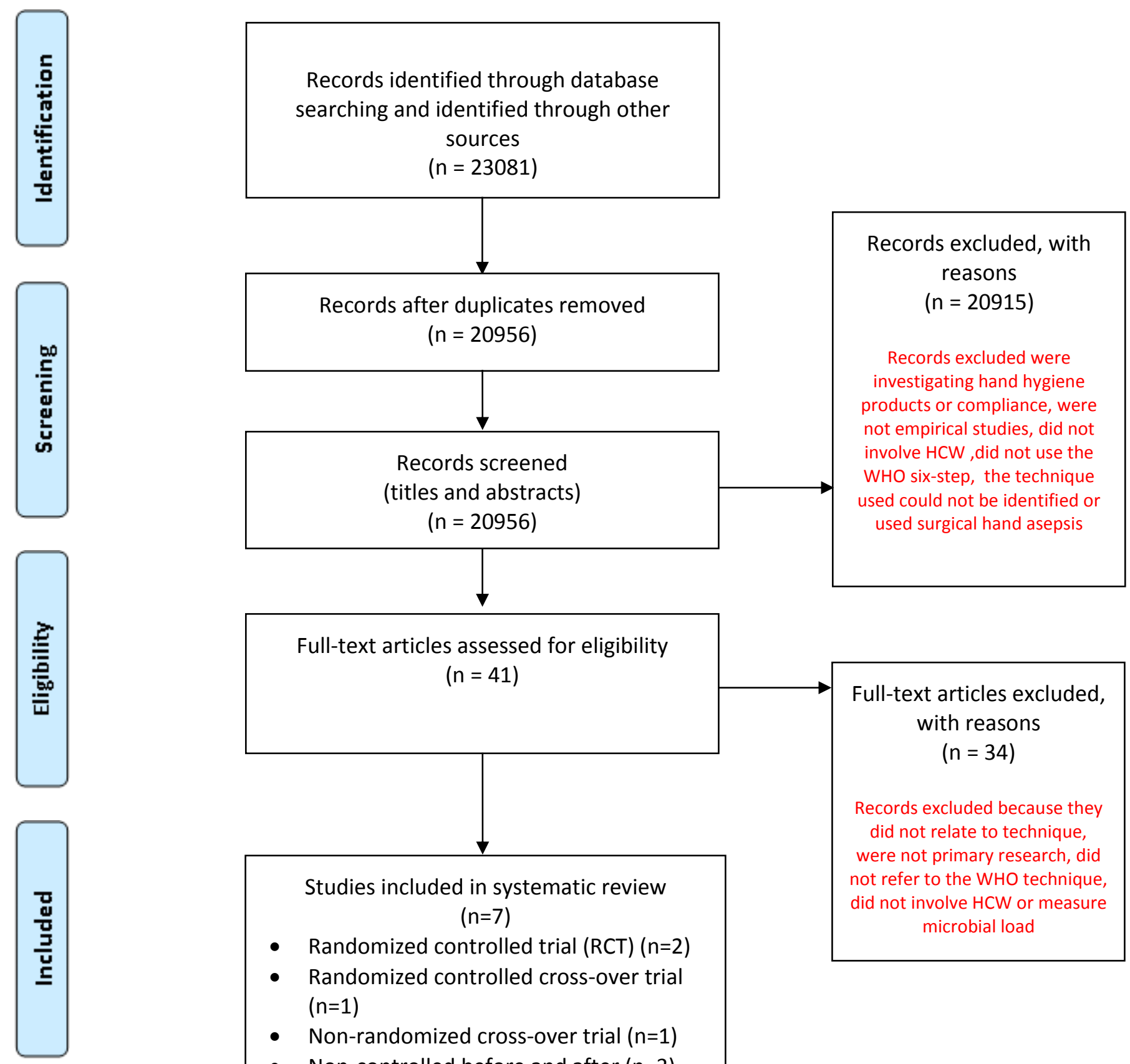

- Randomized controlled cross-over trial $(n=1)$

- Non-randomized cross-over trial $(n=1)$

- Non-controlled before and after $(n=3)$ 
1 Table 1 Characteristics of studies

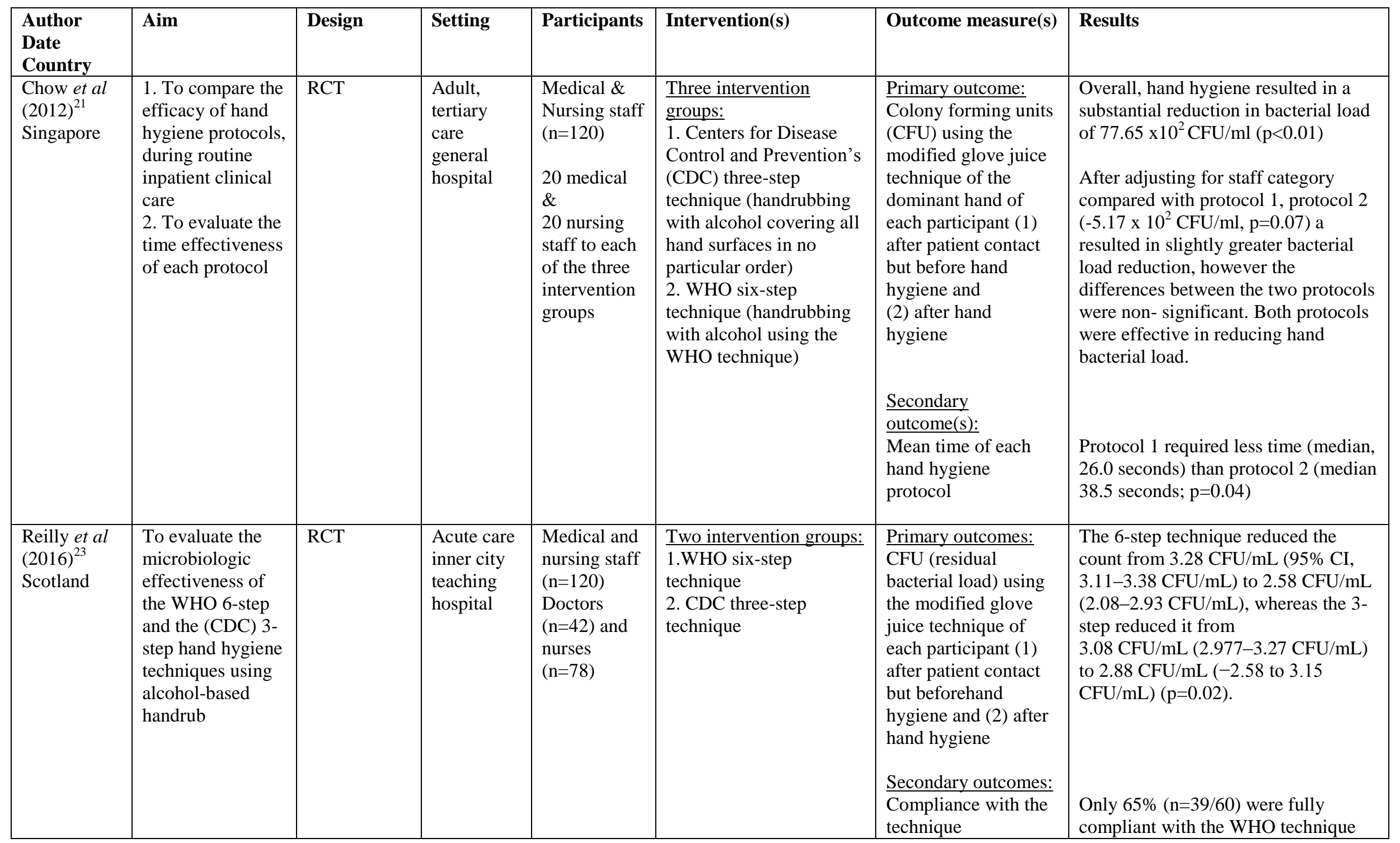




\begin{tabular}{|c|c|c|c|c|c|c|c|}
\hline & & & & & & Hand coverage & $\begin{array}{l}\text { i.e. followed the instructions exactly. } \\
\text { Among those fully compliant, the } \\
\text { median bacterial } \\
\text { load went from } 3.18 \text { (before) to } 2.08 \\
\text { (after hand hygiene) } \log _{10} \\
\text { CFU/mL, compared with } 3.36 \\
\text { (before) to } 2.55 \text { (after hand } \\
\text { hygiene) log } 10 \text { CFU/mL among those } \\
\text { not fully compliant (p=0.01) } \\
\text { No significant difference in total hand } \\
\text { coverage between WHO ( } 98.8 \% \text { ) vs } \\
\text { CDC technique ( } 99.0 \% \text {, p=0.15) } \\
\text { Percentage of hand area not covered } \\
\text { WHO technique (Median } 1.20 \text { ) CDC } \\
\text { technique (Median } 102 \text { p=0.97) } \\
\text { The WHO technique required } 15 \% \\
\text { (95\% Cl, 6- } 24 \% \text { ) more time than the } \\
\text { CDC technique ( } 42.5 \text { vs } 35 \text { seconds, } \\
\text { p=0.002) }\end{array}$ \\
\hline $\begin{array}{l}\text { Tschudin- } \\
\text { Sutter } \text { et al. } \\
(2017)^{24} \\
\text { Switzerland }\end{array}$ & $\begin{array}{l}\text { To assess a } \\
\text { modified three- } \\
\text { step technique } \\
\text { and compare it to } \\
\text { the conventional } \\
\text { WHO six-step } \\
\text { technique in terms } \\
\text { of bacterial counts } \\
\text { reduction on } \\
\text { HCW hands }\end{array}$ & $\begin{array}{l}\mathrm{RCT} \\
\text { (crossover) }\end{array}$ & $\begin{array}{l}\text { University } \\
\text { hospital }\end{array}$ & $\begin{array}{l}\text { Medical } \\
\text { students } \\
(n=32)\end{array}$ & $\begin{array}{l}\text { Intervention group: } \\
\text { Modified three-step } \\
\text { technique consisting of: } \\
\text { a. covering all surfaces } \\
\text { of the hands } \\
\text { b. rotational rubbing of } \\
\text { fingertips in the palm of } \\
\text { the alternate hand } \\
\text { c. rotational rubbing of } \\
\text { both thumbs } \\
\text { Control group: } \\
\text { WHO six-step technique }\end{array}$ & $\begin{array}{l}\text { Primary outcome: } \\
\text { CFU using the } \\
\text { modified glove juice } \\
\text { technique }\end{array}$ & $\begin{array}{l}\text { Pre hand hygiene: } \\
\text { Log bacterial counts did not differ } \\
\text { between the control group (WHO } \\
\text { technique) (median } 6.37 \log _{10} \mathrm{CFU} \text {, } \\
\text { IQR 6.19-6.54) and the intervention } \\
\text { group (median } 6.34 \log _{10} \mathrm{CFU}, \mathrm{IQR} \\
6.17-6.60 \text {, one-sided p=0.513) } \\
\text { Post hand hygiene: } \\
\text { Reductions in CFU were evident for } \\
\text { both intervention and control groups. } \\
\text { There were lower bacterial counts in } \\
\text { the intervention group (median } 1.96 \\
\log _{10} \text { CFU, IQR 1.25-2.52) compared } \\
\text { to control group (median 2.34 } \log _{10}\end{array}$ \\
\hline
\end{tabular}




\begin{tabular}{|c|c|c|c|c|c|c|c|}
\hline & & & & & & & $\begin{array}{l}\text { CFU, IQR } 1.80-2.71 \text {, one-sided } \\
\mathrm{p}=0.055 \text { ) } \\
\text { The logarithmic reduction factor was } \\
\text { higher in the intervention group } \\
\text { (median } 4.45 \log _{10} \text { CFU, IQR } 4.04- \\
5.15 \text { versus } 3.91 \log _{10} \text { CFU, IQR } \\
\text { 3.69-4.62, one-sided p-value=0.010, } \\
\text { two-sided p-value } 0.021 \text { ) }\end{array}$ \\
\hline $\begin{array}{l}\text { Laustsen et } \\
\text { al. } \\
(2008)^{7} \\
\text { Denmark }\end{array}$ & $\begin{array}{l}\text { To investigate the } \\
\text { use of the correct } \\
\text { application of } \\
\text { WHO six-step } \\
\text { technique } \\
\text { before and after } \\
\text { performance of a } \\
\text { clinical procedure }\end{array}$ & $\begin{array}{l}\text { Non- } \\
\text { controlled } \\
\text { before and } \\
\text { after }\end{array}$ & $\begin{array}{l}\text { University } \\
\text { hospital }\end{array}$ & $\begin{array}{l}\text { Staff } \\
\text { members } \\
\text { from } 10 \\
\text { departments } \\
\text { working } \\
\text { during a } \\
\text { randomly } \\
\text { chosen } \\
\text { weekday } \\
\text { (n=117). } \\
\text { Staff } \\
\text { members } \\
\text { with hand } \\
\text { dermatitis } \\
\text { were } \\
\text { excluded } \\
\text { (n=2) }\end{array}$ & $\begin{array}{l}\text { WHO six-step technique } \\
\text { before \& after a clinical } \\
\text { procedure) }\end{array}$ & $\begin{array}{l}\text { Primary outcome: } \\
\text { CFU from finger } \\
\text { imprint technique of } \\
\text { the dominant hand }\end{array}$ & $\begin{array}{l}\text { Before clinical procedure: } \\
\text { Imprint 1- before WHO technique } \\
\text { Imprint 2- after WHO technique } \\
56 \% \text { ( }=66 / 117 \text { ) performed correct } \\
\text { WHO technique } \\
\text { Correct use of WHO six-step } \\
\text { technique significantly reduced } \\
\text { number of CFUs by 90\% (from 18.1 } \\
\text { CFU per plate [95\% CI, 13.5-24.2] to } \\
1.8 \text { CFU per plate [95\% CI, 1.1-2.7]; } \\
\text { p<0.001) } \\
\text { Incorrect use of WHO six-step } \\
\text { technique significantly reduced } \\
\text { number of CFUs by } 60 \% \text { (from } 25.5 \\
\text { CFU per plate [95\% CI, 18.4-35.1] to } \\
10.2 \text { CFU per plate [95\% CI, 7.2- } \\
14.3 \text { ]; p<0.001) } \\
\text { After clinical procedure: } \\
\text { Imprint 3- before WHO technique } \\
\text { Imprint 4- after WHO technique } \\
58 \% \text { (n=68/117) performed correct } \\
\text { WHO handrub technique } \\
\text { Correct use of WHO handrub } \\
\text { technique significantly reduced the } \\
\text { number of CFUs by } 82 \% \text { (from } 10.0 \\
\text { CFU per plate [95\% CI, 7.4-13.5] to } \\
1.8 \text { CFU per plate [95\% CI, } 1.1-2.7 \text {; } \\
\text { p<0.001) } \\
\text { Incorrect use of WHO handrub }\end{array}$ \\
\hline
\end{tabular}




\begin{tabular}{|c|c|c|c|c|c|c|c|}
\hline & & & & & & & $\begin{array}{l}\text { technique significantly reduced the } \\
\text { number of CFUs by } 54 \% \text { (from } 16.3 \\
\text { CFU per plate [95\% CI,11.6-22.7] to } \\
7.5 \text { CFU per plate [95\% CI, 5.2- } \\
10.7] \text {; p }<0.001 \text { ) }\end{array}$ \\
\hline $\begin{array}{l}\text { Pires et al. } \\
(2017)^{22} \\
\text { Switzerland }\end{array}$ & $\begin{array}{l}\text { To evaluate } \\
\text { whether } \\
\text { modifying the } \\
\text { sequence of the } \\
\text { WHO technique } \\
\text { by performing } \\
\text { step } 6 \text { first would } \\
\text { result in greater } \\
\text { bacterial } \\
\text { reduction on } \\
\text { HCW hands }\end{array}$ & $\begin{array}{l}\text { Non- } \\
\text { randomized } \\
\text { cross-over } \\
\text { trial }\end{array}$ & $\begin{array}{l}\text { University } \\
\text { hospital }\end{array}$ & $\begin{array}{l}\begin{array}{l}\text { Healthcare } \\
\text { workers } \\
(\mathrm{n}=16)\end{array} \\
\text { Nurses }(\mathrm{n}=7) \\
\text { and medical } \\
\text { doctors/phar } \\
\text { macists/biol } \\
\text { ogists }(\mathrm{n}=9)\end{array}$ & $\begin{array}{l}\text { Two intervention groups: } \\
\text { 1. WHO six-step } \\
\text { technique } \\
\text { 2. Modified version, } \\
\text { WHO "Fingertips } \\
\text { First" }\end{array}$ & $\begin{array}{l}\text { Primary outcome: } \\
\text { CFU retrieved from } \\
\text { finger imprint } \\
\text { technique at baseline } \\
\text { and after each of the } \\
2 \text { different techniques }\end{array}$ & $\begin{array}{l}\text { Overall, the } \log _{10} \text { reduction in } \\
\text { bacterial concentration was } \\
\text { significantly higher when performing } \\
\text { the WHO "Fingertips First" } \\
(3.44( \pm 1.33,3.20)) \text { compared with } \\
\text { the WHO six-step technique }(2.68 \\
( \pm 1.48,2.85)) \\
\\
\text { After adjustment for hand size } \\
\text { and gender, the mean reduction of } \\
\text { bacterial concentration was } \\
0.77 \text { log10 greater }(95 \% \text { CI, } 0.27- \\
1.26 ; \text { p=0.002) following the WHO } \\
\text { "Fingertips First" technique than } \\
\text { following the WHO six-step } \\
\text { technique }\end{array}$ \\
\hline
\end{tabular}




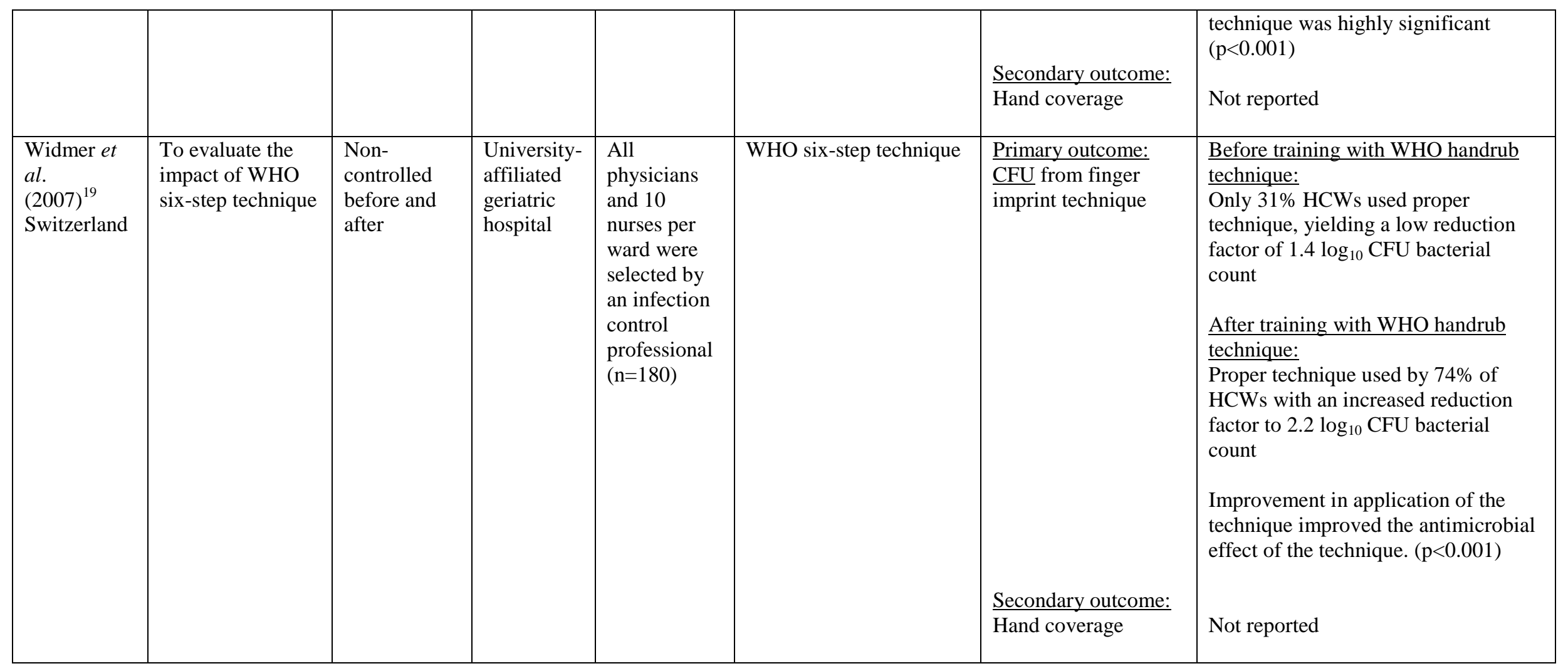


According to the Cochrane Effective Practice and Organisation of Care (EPOC) study design criteria, ${ }^{26}$ of the studies included, two were $\mathrm{RCTs},{ }^{21,23}$ one was a randomized controlled cross-over trial, ${ }^{24}$ three were controlled before and after studies ${ }^{7,19,20}$ and one was a nonrandomized cross-over trial. ${ }^{22}$ All studies used alcohol-based handrub (ABHR) to investigate some aspect of the WHO six-step hand hygiene technique with the primary outcome of bacterial load on the hands of HCW measured in colony forming units (CFU). Secondary outcomes of time and hand coverage were assessed in two ${ }^{21,23}$ and three ${ }^{19,20,23}$ studies respectively. The settings for six studies were hospitals ${ }^{7,19,21-24}$ with one being a University ${ }^{20}$ and participants were doctors and nurses with two studies focusing solely on medical students. $^{20,24}$ Study outcomes and methodological quality of the RCTs and other study designs are subsequently discussed.

\section{Primary outcomes}

$R C T s$

Tschudin-Sutter et al (2017), ${ }^{24}$ Reilly et al (2016) ${ }^{23}$ and Chow et al (2012), ${ }^{21}$ all demonstrated a reduction in bacterial load following the application of the WHO six-step technique. However, findings were inconsistent. Chow et al $2012^{21}$ found that the WHO six-step technique was no more effecting than covering all surfaces of the hands in no particular order (the Centers for Disease Control and Prevention's (CDC) three-step technique) ( $\mathrm{p}=0.07)$. In contrast, Reilly et al $(2016)^{23}$ demonstrated that the WHO six-step technique was more effective than the CDC three-step technique $(\mathrm{p}=0.02)$. Similarly to Reilly et al $(2016){ }^{23}$ Tschudin-Sutter et al $(2017)^{24}$ also compared a three-step technique to the WHO six-step technique. This three-step technique was different from that used by Chow et al $(2012)^{21}$ in that it consisted of covering all surfaces of the hands, and in addition, rotational rubbing of fingertips in the palm of the alternate hand and rotational rubbing of both thumbs and was 
found to be more effective at reducing bacterial load than the WHO six-step technique $(\mathrm{p}=0.021)$.

Other study designs

Again, all studies showed a reduction in bacterial load on the hands of HCW using the WHO six-step technique. However, there were differences in findings across the studies. TschudinSutter et al $(2010)^{20}$ demonstrated that the bacterial load on the hands of medical students was reduced after the use of the WHO six-step technique $(\mathrm{p}<0.001)$. Laustsen et al $(2008)^{7}$ and Widmer et al $(2007)^{19}$ reported that when participants either performed the WHO six-step technique correctly, or incorrectly, there was a reduction in the bacterial load; however the correct application, as compared to the incorrect application of the technique revealed a greater reduction (Widmer $\mathrm{p}<0.001$, Laustsen $\mathrm{p}=$ not reported). This finding was also supported by Reilly et al $(2016)^{23}$ who demonstrated a significant difference in those who had performed the WHO six-step technique with $100 \%$ accuracy when compared to those who had not $(\mathrm{p}=0.01)$. Finally, Pires et al $(2017)^{22}$ reported that a modified "Fingertips first" WHO six-step technique had a greater reduction in bacterial load than the currently recommended WHO six-step technique $(\mathrm{p}=0.002)$.

Secondary outcomes all studies

Secondary outcome measures were mean time of hand hygiene and hand coverage.

\section{Median time of hand hygiene}

Chow et al (2012) $)^{21}$ and Reilly et al (2016) $)^{23}$ both monitored the median time for conducting hand hygiene using the WHO six-step and the CDC three-step techniques and reported a single median time for each respectively. In the study by Chow et al (2012), ${ }^{21}$ despite the CDC three-step technique requiring significantly less time than the WHO six-step technique to complete ( $\mathrm{p}=0.04)$, it was still as effective in reducing bacterial load. In contrast, Reilly et 
al (2016) ${ }^{23}$ showed that the WHO six-step technique was more effective than the CDC threestep technique but agreed that it took longer to perform $(\mathrm{p}=0.002)$.

\section{Hand coverage}

Widmer et al (2007) ${ }^{19}$ and Tschudin-Sutter et al $(2010)^{20}$ examined hand coverage using a UV light box to detect areas missed on the hands following hand hygiene but did not report specific results on this. Reilly et al $(2016)^{23}$ also evaluated hand coverage and found that the WHO six-step technique did not increase the total hand coverage area $(\mathrm{p}=0.15)$ and a reduction in bacterial count was not related to hand coverage $(\mathrm{p}=0.97)$.

\section{Methodological quality of RCTs}

Chow et al $(2012)^{21}$ and Reilly et al $(2016)^{23}$ both used a parallel group, randomized controlled trial to compare the microbiological effectiveness of the WHO six-step and the simpler CDC three-step hand hygiene techniques. Both studies used pre-prepared sealed envelopes to allocate participants, ${ }^{21,23}$ thereby reducing selection bias. The robustness of the studies were also enhanced through blinding of the microbiologists, ${ }^{21,23}$ thereby reducing detection bias. However, the data collectors were not blinded to the allocated protocols in either study ${ }^{21,23}$ because they timed the performance of the allocated hand hygiene technique and performed the glove juice technique for collection of the microbiological sample. They were however trained in the application of the glove juice technique and timing of the hand hygiene technique thereby enhancing reliability of the data collection methods, ${ }^{21,23}$ but neither study tested the inter-rater reliability of the data collectors.

Tschudin-Sutter et al $(2017)^{24}$ performed a randomized cross-over trial to assess a modified three-step technique (intervention group) against the WHO six-step technique (WHOreference group) in terms of bacterial load reduction. Participants were randomly assigned to each group and then assignments reversed after one day. Unlike the previous studies, ${ }^{21,23}$ Tschudin-Sutter et al (2017) ${ }^{24}$ did not mention blinding of the data collectors, who performed 
the glove juice technique for the collection of the microbiological sample or if the data collectors had completed any training. It is difficult therefore to assess the reliability of the data collection process in this study. The studies by Chow et al $(2012)^{21}$ and Reilly et al $(2016)^{23}$ were powered and recruitment targets were achieved, ${ }^{21,23}$ whilst Tschudin-Sutter $e t$ al $(2017)^{24}$ made no mention of this and so it is unknown whether their sample size was adequate.

All three studies used the modified glove juice sampling method. ${ }^{21,23,24}$ Chow et al $(2012)^{21}$ state that this method provides a more accurate measurement of the actual bacterial burden which could be transferred via hand contact. However, it could be argued that the glove juice method will be measuring the reduction in resident as well as transient skin flora. Thus, although the RCTs using this method demonstrated reductions in CFU, they were not necessarily measuring reductions relevant to the transmission of infection in a clinical setting. Furthermore, the CFU detected after patient contact but pre hand hygiene would be affected by the number of transient organisms acquired during the clinical procedure(s). In addition, the glove juice sampling technique might have also removed some bacteria from participants' hands before ABHR was applied, thereby overestimating the bacterial reduction. This number will vary considerably and if the comparison of reduction outcomes is valid then evidence is required to show that there is a true random distribution of contamination density across the two groups. It is unknown whether this can be guaranteed in a relatively small sample of clinicians delivering different aspects of care and therefore this is a flaw of these study designs. There are also several other limitations of these studies. Unlike Reilly et al (2016), ${ }^{23}$ Chow et al $(2012)^{21}$ were unable to ascertain whether specific areas of the hand had been missed by the hand hygiene techniques because they did not evaluate hand coverage and sites missed. Previous studies ${ }^{8,19}$ have shown that the thumb and fingertips are the most frequently missed areas on the hands. In the study by Reilly et al (2016), ${ }^{23}$ correlation 
between bacterial reduction and hand surface coverage is also a limitation because these data were collected at two different time points. Therefore, Reilly et al (2016) ${ }^{23}$ could not be certain that the technique was conducted by participants in exactly the same way each time, although standardization by showing each participant an instruction card with a diagram of the allocated technique should have helped to minimise the risk.

\section{Methodological quality of other study designs}

Four of the included studies were designs other than RCTs. The sample size in these studies ranged from 7-563. ${ }^{7}, 19,20,22$ None of these studies mention if they were powered and so it is unknown whether their sample sizes were adequate for the analysis they performed. The sampling strategy varied in the different studies with three out of four studies ${ }^{19,20,22}$ using a non-randomized strategy and thereby being prone to selection bias.

All four studies used a different sampling method, involving finger imprint technique, compared to the RCTs. A limitation of the finger imprint technique is it only allows bacterial measurement from the fingertips and as the study by Reilly et al (2016) ${ }^{23}$ revealed, the back of the hands, the back of the thumbs and the back of the index fingers were the most frequently missed sites regardless of the technique used. However, it could be argued that the finger imprint technique is perhaps a more valid method of bacterial measurement in terms of transmission of infections because it solely removes transient organisms.

Finally only two of the four studies mentioned training data collectors. ${ }^{7,19}$ In both of these studies a high inter-rate agreement was obtained prior to data collection, enhancing reliability in these two studies. However, despite this, these studies ${ }^{7,19,20}$ had no control groups making it difficult to differentiate between the observed effect being due to the hand hygiene technique or other confounding variables, thereby affecting the validity of the outcomes.

\section{Discussion}


Hand hygiene is described as the single most important intervention to reduce the risk of cross transmission of infection. ${ }^{1}$ Despite this, to the authors' knowledge, this is the first systematic review to evaluate the evidence for the WHO technique reducing the microbial load on the hands of HCW. All seven included studies found the WHO six-step technique reduced bacterial load on the hands of $\mathrm{HCW}$, however the strongest evidence came from three RCTs, which provided conflicting evidence. Chow et al $(2012)^{21}$ found no difference in the effectiveness of the WHO six-step compared to the CDC three-step technique, whilst in contrast, Reilly et al (2016) ${ }^{23}$ found the WHO six-step to be more effective. Tschudin-Sutter et al $(2017)^{24}$ revealed that a modified three-step technique which focussed on the fingertips and thumbs was more effective than the WHO six-step technique. These three studies were all conducted in a hospital setting, therefore it should be noted that these findings are relevant to this particular healthcare setting. The remaining evidence comes from studies with poor quality research designs due to their lack of randomization and control groups, thus limited conclusions can be drawn from these studies.

Of particular note is Chow's et al (2012) ${ }^{21}$ finding that coverage of all aspects of the hands was as effective as the WHO six-step technique and quicker. This also supports similar findings from the study by Tschudin-Sutter et al $(2017)^{24}$ and from an earlier study by Kampf et al (2008), ${ }^{8}$ which was not included in this review as it included non-healthcare participants. However, the former study used a different technique from Chow et al (2012) ${ }^{21}$ as it included fingertip and thumb rubbing steps. Having a simple and quick technique, effectively reducing key reported behavioural barriers, ${ }^{1}$ could be important in clinical practice as it may increase compliance and potentially improve hand hygiene practice within the clinical setting, given that suboptimal rates of HCW compliance with the WHO six-step technique has been previously reported in studies worldwide. ${ }^{13-15}$ However, there are limits to the amount of time that can be saved with different techniques, as according to current 
understanding, when using ABHR the hands should be allowed to dry after performing 'the technique' and before proceeding. ${ }^{1}$

Interestingly Reilly et al $(2016)^{23}$ found that the efficacy of the WHO six-step technique to be enhanced when performed with $100 \%$ accuracy (correct steps, correct order), whereas Pires et al (2017), ${ }^{22}$ showed that efficacy was enhanced for the WHO six-step technique when the order of performance of steps was changed with the finger tips, normally the last step, was performed first. This not only raises question about what technique is best but can the techniques be modified to enhanced their performance.

From the body of evidence as a whole, it is difficult to differentiate between the efficacy of the different hand hygiene techniques. In addition, potential confounding factors such as time taken to perform hand hygiene and accuracy in performance of the technique have not always been controlled for and may have influenced the results.

Historically, in infection prevention and control studies, the default research design has been observational studies; however, randomized controlled studies of hand hygiene technique as shown in this review are possible. The studies included provide some relevant and interesting findings that demonstrate that the technique reduces bacterial load on HCW hands but overall the level of evidence is low and generalizability of the findings is limited. They can however form the basis for further, more robust studies. It is therefore recommended that RCTs directly comparing the effectiveness of the different techniques are performed in clinical practice.

\section{Conclusion}

\section{Implications for Practice}

Although this review provides evidence supporting the use of the WHO six-step hand hygiene technique in clinical practice, it is evident that further research involving more robust 
research designs requires to be undertaken to identify the best hand hygiene technique. Compliance with recommended hand hygiene is suboptimal and improving current techniques or inventing new ones may help to improve this. However, hand hygiene is an essential part of the recommendations in infection prevention and control measures and current practice should be maintained while such further evidence is gathered.

\section{Implications for Research}

Further robust research, using well-designed RCTs which specifically focus on the different hand hygiene techniques is then required to determine which hand hygiene technique is the most effective and in what context. Bacterial load on the hands of healthcare staff before and after application of techniques during clinical practice in acute hospitals, controlling the time of application, product used and including inter-rater reliability testing of data collectors, blinding of microbiologists and adequate sample sizes to power the studies are all required. Randomization of the population should help to control for differences in participant's experience, previous training and expectations of the hand hygiene technique but reporting of these data will demonstrate if this has been achieved. The use of glove juice or finger imprint technique for the collection of microbiological samples appears to be open to debate. The European EN1500 guidelines, ${ }^{27}$ recommend the finger imprint method, whilst in the USA the Food and Drug Administration ${ }^{28}$ advise the glove juice method, when conducting experiments on hand hygiene. Secondary outcomes could include the reduction in the number and type of organism. With regard to performing hand hygiene systematic reviews our search retrieved a large number of papers that needed to be excluded because they were not empirical studies. We recommend that others performing similar searches include study design as one of the domains of their search. Finally, when reporting the findings of hand hygiene research this review has highlighted the need to include a thorough description of the 
hand hygiene techniques, sampling strategy and the population/sample in the study, using reporting templates such as Consort, ${ }^{29}$ Strobe $^{30}$ and Orion. ${ }^{31}$

This Review has contributed to illustrating the state of current evidence for the WHO hand hygiene technique in reducing microbial load on the hands of HCW. The findings provide direction for current practice and for further research. Hand hygiene research must continue to evolve to inform global action to prevent and control HAI and contain antimicrobial resistance.

\section{Acknowledgements}

We would like to thank Marion Kelt, Librarian at Glasgow Caledonian University, for her help with the search strategy.

\section{References}

1. World Health Organisation. WHO Guidelines for Hand Hygiene in Health Care. First Global Patient Safety Challenge. Clean Care is Safer Care. WHO, Geneva, 2009.

2. El Shafie SS, Alishaq M, Leni Garcia M. Investigation of an outbreak of multidrugresistant Acinetobacter baumannii in trauma intensive care unit. J Hosp Infect 2004; 56: 101-105.

3. Wong, T., Tam, W.W. Handwashing practice and the use of personal protective equipment among medical students after the SARS epidemic in Hong Kong. Am J Infect Control 2005; 33(10): 580-586.

4. Pittet D. Hand hygiene: it's all about when and how (Commentary), Infect Control and Hosp Epidemiol 2008; 29(10): 957-959.

5. Pittet D, Hugonnet S, Harbarth S, Mouraga P, Sauvan V, Touveneau S, et al. Effectiveness of a hospital-wide programme to improve compliance with hand hygiene. Lancet 2000; 356:1307-1312. 
6. Lucet J-C, Rigaud M-P, Mentre F, Kassis N, Deblangy C, Andremont A, et al. Hand contamination before and after different hand hygiene techniques: a randomized clinical trial. J Hosp Infect 2002; 50: 276-280.

7. Laustsen S, Lund E, Bibby BM, Kristensen B, Thulstrup AM, Mǿller JK. Effect of Correctly Using Alcohol-Based Hand Rub in a Clinical Setting. Infect Control and Hosp Epidemiol 2008; 29(10): 954-956.

8. Kampf G, Reichel M, Feil Y, Eggerstedt S, Kaulfers P-M. Influence of rub-in technique on required application time and hand coverage in hygienic hand disinfection. BMC Infectious Diseases 2008; 8:149-159.

9. Pittet D, Allegranzi B, Sax H, Dharan S, Pessoa-Silva C, Donaldson L, et al. Evidence-based model for hand transmission during patient care and the role of improved practices. Lancet Infections Diseases 2006; 6:641-652.

10. Girou E, Loyeau S, Legrand P, Oppein F, Brun-Buisson C. Efficacy of handrubbing with alcohol based solution versus standard handwashing with antiseptic soap: randomised controlled trial. BMJ 2002; 325:1-5.

11. Ayliffe GA, Babb J, Quoraishi AH. A test for 'hygienic' hand disinfection. J Clin Pathol 1978; 31(10): 923-928.

12. Pittet D, Allegranzi B, Boyce J, for the WHO World Alliance for Patient Safety First Global Patient Safety Challenge Core Group of Experts. The WHO Guidelines on Hand Hygiene in Health Care and their Consensus Recommendations. Infect Control and Hosp Epidemiol 2009; 30(7):611-622.

13. Arias AV, Garcell HG, Ochoa YR, Arias KF, Miranda FR. Assessment of hand hygiene techniques using the World Health Organization's six steps. J Infect Public Heal 2016; 9: 366-369. 
14. Park H-Y, Kim S-K, Lim Y-J, Kwak S-H, Hong M-J, Mun H-M, et al. Assessment of the appropriateness of hand surface coverage for health care workers according to World Health Organization hand hygiene guidelines. Am J Infect Control 2014; 42: $559-561$.

15. Thivichon-Prince B, Barsotti O, Girard R, Morrier J-J. Hand hygiene practices in a dental teaching center: measures and improve. Eur J Dent 2014; 8: 481-486.

16. Grayson ML, Macesic N, Huang GK, Bond K, Fletcher J, Gilbert GL, et al. Use of an Innovative Personality-Mindset Profiling Tool to Guide Culture-Change Strategies among Different Healthcare Worker Groups. PLoS ONE 2015; 10(10): e0140509. https://doi.org/10.1371/journal.pone.0140509

17. Price L, Cuthbertson L, McLarnon N, Kilpatrick C, Bunyan D, Reilly J. JBI review protocol 531. A systematic review of the evidence for Ayliffe's six-step hand hygiene technique used by healthcare workers. Joanna Briggs Library of Systematic Reviews 2012; 9(32): S102-117

18. Joanna Briggs Institute, Reviewers Manual 2011 Edition. The Joanna Briggs Institute, The University of Adelaide. Available at: http://joannabriggs.org/assets/docs/sumari/ReviewersManual-2011.pdf [accessed 25th July 2014.

19. Widmer AF, Conzelmann M, Tomic M, Frei R, Stranden AM. Introducing alcoholbased hand rub for hand hygiene: the critical need for training. Infect Control and Hosp Epidemiol 2007; 28(1): 50-54.

20. Tschudin-Sutter ST, Frei R, Dangel M, Widmer AF. Effect of teaching recommended world health organization technique on the use of alcohol-based hand rub by medical students. Infect Control and Hosp Epidemiol 2010; 31(11): 1194-1195. 
21. Chow A, Arah OA, Chan S-P, Poh B-F, Krishnan P, Ng W-K, et al. Alcohol handrubbing and chlorhexidine handwashing protocols for routine hospital practice: A randomized clinical trial of protocol efficacy and time effectiveness. Am J Infect Control 2012; 40(12): 800-805.

22. Pires D, Bellissimo-Rodrigues F, Soule H, Gayet-Ageron A, Pittet D. Revisiting the WHO "How to Handrub" Hand Hygiene Technique: Fingertips First? Infect Control and Hosp Epidemiol 2017; 38(2): 230-233.

23. Reilly JS, Price L, Lang S, Robertson C, Cheater F, Skinner K, et al. A Pragmatic Randomized Controlled Trial of 6-Step vs 3-Step Hand Hygiene Technique in Acute Hospital Care in the United Kingdom. Infect Control and Hosp Epidemiol 2016; 37(6): 661-666.

24. Tschudin-Sutter S, Rotter ML, Frei R, Nogarth D, Häusermann P, Stranden A, et al. Simplifying the WHO "how to hand rub" technique: three steps are as effective as sixresults from an experimental randomized cross-over trial. Clin Microbiol Infect 2017; 23(6): 409:e1-409.e4.

25. Moher D, Liberati A, Tetzlaff J, Altman DG. PRISMA Group. Preferred reporting items for systematic reviews and meta-analyses: the PRISMA statement. BMJ 2009 Jul 21;339:b2535.

26. Effective Practice and Organisation of Care (EPOC). What study designs should be included in an EPOC review and what should they be called? Available at: http://epoc.cochrane.org/sites/epoc.cochrane.org/files/public/uploads/EPOC\%20Study \%20Designs\%20About.pdf [accessed $12^{\text {th }}$ September 2017].

27. BSI Standards Publication. Chemical disinfectants and antiseptics- Hygienic handrubTest method and requirements (phase2/step2). BS EN1500 2013; 1-42. 
28. Food and Drug Administration (FDA). Tentative final monograph for healthcare antiseptic drug products; proposed rule. Federal Register 1994; 59: 31441--52

29. CONSORT- Transparent reporting of trials. Available at: http://www.consortstatement.org [accessed $20^{\text {th }}$ October 2017].

30. STROBE Statement- Strengthening the reporting of observational studies in epidemiology. Available at: http://www.strobe-statement.org/?id=available-checklists [accessed $20^{\text {th }}$ October 2017].

31. IDRN Orion Statement. Available at: http://www.idrn.org/orion.php [accessed 20th October 2017]. 


\section{Appendix}

\begin{tabular}{|c|c|}
\hline \multicolumn{2}{|c|}{ Search Terms } \\
\hline \multicolumn{2}{|c|}{ Context } \\
\hline 1 & (MH “Delivery of Health Care") \\
\hline 2 & (Healthcare OR health care OR health): ti,ab \\
\hline \multicolumn{2}{|c|}{ Population } \\
\hline 3 & (MH “Health personnel”) OR “personnel”: ti,ab \\
\hline 4 & (MH "Allied health personnel") \\
\hline 5 & $\begin{array}{l}\text { (MH “emergency medical technicians") OR "emergency medical technician*”: } \\
\text { ti,ab }\end{array}$ \\
\hline 6 & (MH “nurses’aides+”) OR “nurses’ aides”: ti,ab \\
\hline 7 & (MH “nutritionists") OR nutritionists: ti,ab \\
\hline 8 & (MH “operating room technicians") OR “operating room technician*”: ti,ab \\
\hline 9 & (MH “physical therapist assistants") OR “physical therapist*”: ti,ab \\
\hline 10 & (MH “physician assistants+") OR "physician assistant*: ti,ab \\
\hline 11 & (MH "infection control practitioners") OR "infection control practitioner*”: ti,ab \\
\hline 12 & (MH “medical laboratory personnel") \\
\hline 13 & (MH “medical staff+") OR “medical staff”: ti,ab \\
\hline 14 & (MH “nurses+") OR nurses: ti,ab \\
\hline 15 & (MH “nursing staff+") OR "nursing staff”: ti,ab \\
\hline 16 & (MH “physicians+") OR physicians: ti,ab \\
\hline 17 & (MH “social workers") OR “worker*”: ti,ab \\
\hline 18 & professional: ti,ab \\
\hline 19 & employee: ti,ab \\
\hline 20 & podiatrist*: ti,ab \\
\hline 21 & "occupational therapist*": ti,ab \\
\hline 22 & dietician*: ti,ab \\
\hline 23 & radiographer*: ti,ab \\
\hline 24 & medic*:ti, ab \\
\hline 25 & physiotherapist*:ti,ab \\
\hline 26 & "dialysis technician*": ti,ab \\
\hline 27 & "dietetic technician*": ti,ab \\
\hline 28 & "pharmacy technician*": ti,ab \\
\hline 29 & "cardiopulmonary technician*”: ti,ab \\
\hline 30 & "cardiovascular technician*": ti,ab \\
\hline 31 & "nuclear medicine technician*": ti,ab \\
\hline 32 & "radiologic technologist*": ti,ab \\
\hline 33 & "orthop\#edic technologist*”: ti,ab \\
\hline 34 & practitioner*:ti, ab \\
\hline \multicolumn{2}{|c|}{ Intervention } \\
\hline 35 & (MH "Hand Hygiene+") OR (“hand hygiene”): ti,ab \\
\hline 36 & (MH "Hand Disinfection") OR (“hand disinfection"): ti,ab \\
\hline 37 & (handwashing OR "hand washing"): ti,ab \\
\hline 38 & ("hand decontamination"): ti,ab \\
\hline 39 & (handrub* OR "hand rub*"): ti,ab \\
\hline 40 & ("hand sanit*"): ti,ab \\
\hline
\end{tabular}




\begin{tabular}{|c|c|}
\hline 41 & ("hand clean*"): ti,ab \\
\hline 42 & ("hand asepsis"): ti,ab \\
\hline 43 & ("hand degerming"):ti, ab \\
\hline 44 & ("hand gel*"): ti,ab \\
\hline 45 & ("alcohol based hand rub*"): ti,ab \\
\hline 46 & ("alcohol based hand sanit*"): ti,ab \\
\hline 47 & (ABHR OR ABHS): ti,ab \\
\hline 48 & Ayliffe*: ti,ab \\
\hline 49 & technique: ti,ab \\
\hline 50 & procedure: ti,ab \\
\hline 51 & approach:ti, ab \\
\hline 52 & method*:ti, ab \\
\hline 53 & practice $^{*}: \mathrm{ti}, \mathrm{ab}$ \\
\hline 54 & guideline*:ti, ab \\
\hline 55 & protocol $^{*}: \mathrm{ti}, \mathrm{ab}$ \\
\hline 56 & recommendation*:ti, ab \\
\hline 57 & ("6 step*" OR "six step*"): ti,ab \\
\hline 58 & (“7 step*” OR “seven step*”): ti,ab \\
\hline 59 & (WHO OR WHO's OR “world health organi?ation*”: ti,ab \\
\hline \multicolumn{2}{|c|}{ Primary Outcomes } \\
\hline 60 & (MH “colony count, microbial+") OR (MH “bacterial load") \\
\hline 61 & $\begin{array}{l}\text { "microbial count" OR "microbial load" OR "microbial contamination" OR } \\
\text { "microbial coloni?ation": ti,ab }\end{array}$ \\
\hline 62 & "colony count": ti,ab \\
\hline 63 & $\begin{array}{l}\text { "bacterial count" OR "bacterial load" OR "bacterial contamination" OR "bacterial } \\
\text { coloni?ation": ti,ab }\end{array}$ \\
\hline 64 & "antibacterial efficacy":ti, ab \\
\hline 65 & "skin flora": ti,ab \\
\hline 66 & microorganism* OR “micro organism*” OR microbes: ti,ab \\
\hline 67 & (MH “Bacteria+") \\
\hline 68 & (MH "Fungi+") \\
\hline 69 & (MH "Infection+") \\
\hline 70 & pathogen* OR bacteria OR virus*OR yeast* OR infection*: ti,ab \\
\hline 71 & ("colony forming units" OR cfu):ti, ab \\
\hline \multicolumn{2}{|c|}{ Secondary Outcomes } \\
\hline 72 & (MH “Disease transmission, infectious") \\
\hline 73 & (MH “infectious disease transmission, professional-to-patient") \\
\hline 74 & (MH “infection control”) \\
\hline 75 & (MH “disease outbreaks+") \\
\hline 76 & (MH “mortality+") \\
\hline 77 & $\begin{array}{l}\text { "disease transmission" OR "infection control" OR "infection prevention" OR } \\
\text { "cross transmission" OR "communicable disease control” OR "communicable } \\
\text { disease prevention" OR "cross infection" OR nosocomia*: ti, ab }\end{array}$ \\
\hline 78 & mortality OR fatalit*: ti, ab \\
\hline 79 & outbreak*: ti, ab \\
\hline 80 & compliance OR adherence: ti,ab \\
\hline \multicolumn{2}{|c|}{ Combining searches } \\
\hline 81 & 1 OR 2 \\
\hline
\end{tabular}




\begin{tabular}{|c|c|}
\hline 82 & $\begin{array}{l}3 \text { OR } 4 \text { OR } 5 \text { OR } 6 \text { OR } 7 \text { OR } 8 \text { OR } 9 \text { OR } 10 \text { OR } 11 \text { OR } 12 \text { OR } 13 \text { OR } 14 \text { OR } 15 \\
\text { OR } 16 \text { OR } 17 \text { OR } 18 \text { OR } 19 \text { OR } 20 \text { OR } 21 \text { OR } 22 \text { OR } 23 \text { OR } 24 \text { OR } 25 \text { OR } 26 \text { OR } \\
27 \text { OR } 28 \text { OR } 29 \text { OR } 30 \text { OR } 31 \text { OR } 32 \text { OR } 33 \text { OR } 34\end{array}$ \\
\hline 83 & $\begin{array}{l}35 \text { OR } 36 \text { OR } 37 \text { OR } 38 \text { OR } 39 \text { OR } 40 \text { OR } 41 \text { OR } 42 \text { OR } 43 \text { OR } 44 \text { OR } 45 \text { OR } 46 \\
\text { OR } 47\end{array}$ \\
\hline 84 & 48 OR 49 OR 50 OR 51 OR 52 OR 53 OR 54 OR 55 OR 56 OR 57 OR 58 OR 59 \\
\hline 85 & $\begin{array}{l}60 \text { OR } 61 \text { OR } 62 \text { OR } 63 \text { OR } 64 \text { OR } 65 \text { OR } 66 \text { OR } 67 \text { OR } 68 \text { OR } 69 \text { OR } 70 \text { OR } 71 \\
\text { OR } 72 \text { OR } 73 \text { OR } 74 \text { OR } 75 \text { OR } 76 \text { OR } 77 \text { OR } 78 \text { OR } 79 \text { OR } 80\end{array}$ \\
\hline 86 & 81 AND 82 AND 83 AND 84 AND 85 \\
\hline 87 & 86 Limits: June2011-June2017, English langu \\
\hline
\end{tabular}

